\title{
TERMINOLOGIJA I KONCEPTUALIZACIJA SEKSUALNOG ISKORIŠTAVANJA DJECE NA INTERNETU'
}

\author{
Lucija Vejmelka \\ Pravni fakultet Sveučilišta u Zagrebu, Studijski centar socijalnog rada \\ $\checkmark$ E-mail: lvejmelka@pravo.hr
}

Jakov Jurinić, magistar socijalnog rada

\begin{abstract}
SAŽETAK
Rijetko koja kaznena djela izazivaju toliku osudu javnosti kao što to čine seksualno zlostavljanje i iskorištavanje djece, no postavlja se pitanje koliko su ista prepoznata i ozbiljno shvaćena kada se odvijaju unutar virtualnog okruženja. Dobar pokazatelj toga su statistike iz kojih je vidljivo kako broj prijava i osuda nije proporcionalan s brojem izrečenih sankcija za spomenuta kaznena djela. Ono što doprinosi svojevrsnoj konfuziji unutar javnog i stručnog diskursa u području seksualnog zlostavljanja i iskorištavanja djece na internetu, jest neujednačena terminologija i različite operacionalizacije izučavanja ovog fenomena. Iz navedenog razloga, autori ovim radom nastoje pobliže definirati oblike zlostavljanja i iskorištavanja nad $\mathrm{i}$ među djecom na internetu što omogućava dublje razumijevanje ovog oblika protupravnog djelovanja.

Slijedom navedenog, svrha ovog rada je razjasniti ključne pojmove i koncepte u području seksualnog iskorištavanja djece i mladih putem interneta te omogućiti pregled znanstvenih spoznaja i nacionalnih statističkih pokazatelja u području seksualnog zlostavljanja i iskorištavanja djece na internetu koji mogu biti od koristi stručnjacima praktičarima u njihovom svakodnevnom radu, znanstvenicima koji planiraju istraživačke nacrte u ovom području te konačno svima koji se bave zaštitom dječje dobrobiti u digitalnom okruženju.
\end{abstract}

Ključne riječi: konceptualizacija cyber zlostavljanja, seksualno zlostavljanje i iskorištavanje djece na internetu, zakonska regulativa, statistički pokazatelji

\section{UVOD}

Ubrzani razvoj moderne tehnologije i korištenje interneta uvodi revolucionarne promjene tradicionalnih načina komunikacije i prenošenja informacija. Korištenje interneta u stalnom je porastu među svim dobnim skupinama, pri čemu je 2018. godine u Europi internet koristilo 89\% stanovništva, što je porast od 29\% u desetogodišnjem razdoblju (European Statistics [Eurostat], 2018). U Hrvatskoj Internet koristi $82 \%$ stanovništva, dok je kod djece i mladih taj postotak još izraženiji, obuhvaćajući gotovo cijelu populaciju djece i mladih, čak 99\% (Državni zavod za statistiku [DZS], 2019, 2020). Internet je svojim globalnim karakterom omogućio brojne prednosti u vidu jednostavnije i brže komunikacije i dijeljenja informacija pa ne čudi što se u posljednjih nekoliko

1 Istraživanje za ovu publikaciju rađeno je u okviru uspostavno istraživačkog projekta "HRVATSKI MONITOR NASILJA: Istraživanje pojavnih oblika, uzroka i procesuiranja delinkventnog nasilja s fokusom na zaštiti posebno ranjivih skupina žrtava (CroViMo)", sufinanciranog od strane Hrvatske zaklade za znanost (UIP-2017-05-8876). Službena stranica projekta: www.violence-lab.eu 
desetljeća iz akademske mreže razvio u široko rasprostranjenu informatičku mrežu (Derenčinović, 2003).

Razne prednosti korištenja interneta, poput jednostavnijeg i bržeg povezivanja i komuniciranja s drugim korisnicima te olakšanog pristupa informacijama, doprinijele su njegovoj popularizaciji u svim dobnim skupinama, a osobito kod djece i mladih. S obzirom na to da se u većini razvijenih zemalja pristup internetu smatra gotovo univerzalnim standardom svake obitelji, a osobito one s djecom, upravo njima informatičko okruženje postaje normativni kontekst razvoja, što ujedno potvrđuju i nalazi dostupnih istraživanja vezanih uz navike korištenja interneta i rizične online aktivnosti djece i mladih (Hrabri telefon i Poliklinika za zaštitu djece i mladih Grada Zagreba, 2014; http://hrkids.online/, Vejmelka, Strabić i Jazvo, 2017; Vejmelka i Majdak, 2014). Nadalje, statistike pokazuju da više od polovice svjetskog stanovništva internetu pristupa preko mobilnih uređaja (Statista, 2019). Navedeno je posebno zabrinjavajuće kada se radi o djeci, koja ukoliko posjeduju mobilni uređaj bivaju izloženija štetnim sadržajima i rizičnim aktivnosti virtualnog okruženja, budući da im isti olakšava pristup eksplicitnom materijalu ili im čak služi kao sredstvo produkcije vlastitog materijala kojeg nerijetko dijele na mreži.

Usporedno s brojnim prednostima korištenja, internet je omogućio i "selidbu" rizičnih i kažnjivih ponašanja u online okruženje. Zbog same naravi virtualnog okruženja kojeg karakterizira osjećaj anonimnosti te povećana dostupnost štetnih sadržaja i olakšano umrežavanje udaljenih korisnika, internet postaje globalna platforma s neograničenim potencijalom širenja štetnih posljedica. Upravo navedene karakteristike virtualnog okruženja omogućuju pojavu novih oblika nasilnih sadržaja i ponašanja koja su po svojoj prirodi u određenim aspektima čak ekstenzivniji od nasilja i zlostavljanja u njihovom offline obliku (Greenfield i Yan, 2006). Navedene determinante online interakcije doprinijele su izučavanju cyber nasilja i zlostavljanja (Corcoran, McGuckin i Prentice, 2015; Tokunaga, 2010; Vejmelka, Strabić i Jazvo, 2017), no usprkos tomu i dalje je prisutan problem konceptualne i terminološke neujednačenosti, kako u znanstvenoj i stručnoj literaturi, tako i unutar javnog diskursa i prakse rada na području seksualnog zlostavljanja i iskorištavanja djece na internetu. Svrha ovog rada ogleda se upravo u razjašnjavanju i definiranju ključnih pojmova i koncepata u području seksualnog iskorištavanja djece i mladih putem interneta s ciljem njihovog potpunijeg shvaćanja i ispravne primjene. Obzirom da su u radu predstavljeni i statistički pokazatelji kaznenih djela seksualnog zlostavljanja i iskorištavanja djece na internetu, uz aktualnu zakonsku regulativu, smjernice, protokole i međunarodne standarde, rad može biti višestruko koristan svim onim stručnjacima koji rade u području zaštite djece iz sektora socijalne skrbi, pravosuđa, policije, zdravstva i obrazovanja.

Rizici korištenja interneta za djecu su brojni, a štetne aktivnosti u kojima je dijete ciljano izabrano kao žrtva od strane drugog djeteta ili odrasle osobe uključuju slučajeve cyber nasilja, zlostavljanja i iskorištavanja djece na internetu. U nastavku slijedi pobliže definiranje navedenih fenomena grubog kršenja dječje dobrobiti u virtualnom okruženju. 


\section{DEFINICIJA I TIPOLOGIJA NASILJA I ZLOSTAVLJANJA DJECE NA INTERNETU}

\section{Izgubljeni u prijevodu: terminološki kaos cyber kriminala i pojmovna difuzija nasilja i zlostavljanja na internetu}

Elektroničko nasilje, zlostavljanje na internetu, cyber nasilje, nasilje putem društvenih mreža, online zlostavljanje, kibernetičko zlostavljanje i ostali slični pojmovi prisutni u medijima i javnom diskursu, često se koriste ne kritički i bez jasnog definiranja fenomena elektroničkog nasilja i zlostavljanja nad i među djecom što doprinosi terminološkom kaosu u ovom području. Ni stručnjaci i istraživači u području elektroničkog ${ }^{2}$ nasilja i zlostavljanja nisu suglasni oko konceptualizacije ovog fenomena. Jedni se zalažu da je primjerice online oblik zlostavljanja među djecom samo podtip ili produžetak tradicionalnog oblika (Olweus, 2012), dok drugi provode studije koje pokazuju strukturne razlike online i tradicionalnog oblika nasilja i zlostavljanja među djecom i mladima (Greene, 2006; Menesini, Nocentini i Calussi, 2011; Shultze-Krumbholz i sur., 2015).

$\mathrm{Na}$ tom tragu, prisutna su suprotstavljena mišljenja autora o specifičnim karakteristikama kaznenih djela u digitalnom okruženju. Naime, dok jedni negiraju postojanje cyber zločina kao specifičnog područja kaznenopravne prakse, drugi se zalažu za uže definiranje istog (Wall, 2004, 2015). Činjenica je da terminologija na ovom području nije ujednačena te da ne postoji općeniti konsenzus što sve obuhvaćaju cyber zločini. Terminološka jasnoća koja počiva na jasnoj i koherentnoj konceptualizaciji smještenoj u nadređene pojmovne kategorije je polazišna osnova izučavanju određenog fenomena. U protivnom, ograničenja različitih konceptualizacija i posljedično razlike u operacionalizacijama, ne dopuštaju komparacije rezultata istraživanja, onemogućuju vođenje realnih statistika počinjenih djela i ograničavaju praćenje trendova na određenom području što ograničava djelovanje u profesionalnoj praksi. Također, izostanak jasne konceptualizacije određenog fenomena, ograničava kreiranje i implementaciju koordiniranih nacionalnih i međunarodnih aktivnosti temeljenih na znanstvenim spoznajama, a usmjerenih suzbijanju kriminalnih aktivnosti, konkretno u području seksualnog zlostavljanja i iskorištavanja djece na internetu. U konačnici i sami znanstveni, praktični te javni diskursi o terminološki i konceptualno difuzno određenom fenomenu postaju dio problema jer kreiraju nesporazume, osnažuju stereotipe te generiraju krive zaključke čime se ujedno sprječava efikasno suzbijanje u ovom slučaju kaznenih djela seksualnog zlostavljanja i iskorištavanja djece u virtualnom okruženju.

Samo digitalno/virtualno okruženje definira se kao prostor stvoren pomoću globalno umreženih računala koji predstavlja simulaciju stvarnog okruženja, istovremeno omogućujući korisnicima komunikaciju, razmjenu informacija i druge oblike interakcije (Holden i Dyar, 2002). Kada je riječ o pitanju cyber ili „kibernetički“ potrebno je naglasiti kako u Hrvatskoj određeni izvori istoznačno koriste pojam cyber (Veresha, 2018; Vuletić, Jeličić i Karačić, 2014) i pojam „kibernetički” (Konvencija o kibernetičkom kriminalu, NN 9/02, 4/04; Nacionalna strategija kibernetičke sigurnosti, NN 108/2015), dok neki autori koriste i pojam "kiber" (Polić, 2006) što zahtijeva podrobnije razjašnjenje. Naime, kibernetika je pojam koji označava interdisciplinarnu znanstvenu disciplinu koja proučava upravljanje bilo kojim sistemom, živim organizmom, mehanizmom ili kombiniranim sistemom (Obradović, 2018; Vojković i Štambuk-Sunjić, 2006). S obzirom na navedenu definiciju

2 Pojam „elektroničko nasilje“ uvriježeno je u domaćem znanstvenom diskursu u području izučavanja vršnjačkih odnosa te će se i u ovom radu dosljedno koristiti u području vršnjačkog nasilja 
pojedini autori kritiziraju korištenje pojma "kibernetičko" pa se kod definiranja kaznenih djela u cyber prostoru zalažu za korištenje engleskih inačica poput cyber-kriminala i cyber-kaznenih djela s obzirom na to da riječ cyber ${ }^{3}$ u hrvatskom nije imala odgovarajući prijevod (Derenčinović i Getoš, 2008; Vojković i Štambuk-Sunjić, 2006). S druge strane, Halonja (2015), stručnjak na području računalnog jezikoslovlja, potvrđuje diferencijaciju od pojma kibernetike te se zalaže za korištenje prefiksa "kiber" ${ }^{\prime 4}$, iako pojedini autori kiber koriste i kao samostalnu riječ (Akrap, 2019). Kako navedeni izraz nije dio ustaljene jezične prakse i nema sustavnog korištenja u znanstveno-stručnom diskursu unutar ovog područja, isti neće biti korišten ni u nastavku ovog rada. Nadalje, Vojković i Štambuk-Sunjić (2006) naglašavaju, kako pod pojam cyber kaznena djela treba svrstavati samo ona kaznena djela kod kojih je uporaba računala ili računalne mreže bitna za biće kaznenog djela, odnosno čini njegov fenomenološki specifikum, a ne sva kaznena djela u kojima se na neki način kao sredstvo izvršenja pojavljuje računalo s pripadnom perifernom opremom. Pojam kibernetički kriminal većinom se koristi za kaznena djela u području kibernetičke sigurnosti, protiv računalnih sustava, programa i podataka, počinjena unutar kibernetičkog prostora uporabom komunikacijskih i informacijskih tehnologija, što je znatno uže shvaćanje od navedenih suvremenih trendova na ovom području, koji obično označavaju široku pojavu štetnog ponašanja koje je nekako povezano sa zlouporabom računala (Nacionalna strategija kibernetičke sigurnosti, NN 108/2015). Kibernetički kriminal po prethodno navedenoj užoj definiciji nije predmet ovog rada i neće se $u$ istom detaljnije obrađivati. Eminentni stručnjak u ovom području David S. Wall (2004), cyber zločine široko definira kao zločinačko i štetno ponašanje koje negativno utječe na dobrobit i kvalitetu života osobe na mreži i šire. Ovako široko postavljena definicija, kojoj su autori ovog rada priklonjeni, nedvojbeno obuhvaća i kaznena djela u cyber prostoru počinjena na štetu djece, uključujući i seksualno zlostavljanje i iskorištavanje djece na internetu.

\section{Prikladnost upotrebe termina dječja pornografija na internetu}

Suvremeni trendovi izučavanja seksualnog iskorištavanja djece na internetu odmiču se od pojma dječje pornografije na internetu. lako definiciju dječje pornografije na internetu nalazimo u relevantnim međunarodnim dokumentima kao i u nacionalnim zakonodavnim odredbama koji će biti detaljno predstavljeni u nastavku rada, stručnjaci kritiziraju ovakvo pojmovno određenje kao neprimjereno te naglašavaju da se takvom definicijom negira zlostavljačka i predatorska priroda pornografskih materijala te trajnost i ozbiljnost posljedica ovog kaznenog djela za ovu posebno ranjivu skupinu žrtava. Interpol je u partnerstvu s 18 relevantnih međunarodnih organizacija izradio smjernice o terminologiji zaštite djece od seksualnog zlostavljanja i seksualnog iskorištavanja, tzv. "Luksemburške smjernice" koje kroz analizu međunarodno obvezujućih dokumenata daju okvir pojmovnih oblika te promiču odgovorno korištenje prikladne terminologije kako bi se izbjeglo banaliziranje i minoriziranje ovog kaznenog djela na štetu djece (Interagency Working Group on Sexual Exploitation of Children, 2016). Naime pojam pornografija dolazi od grčkih riječi porni i graphein te u doslovnom prijevodu znači ilustriranje bludničenja, a bludničenje uključuje spremnost, pristanak i namjeru činjenja bludnih radnji (https://www.britannica.com/topic/pornography). Neupitno je da navedeni prijevod po samoj logici stvari nije prihvatljiv u odnosu na djecu i maloljetnike kao što može biti primjenjiv u komercijalno prihvatljivom pornografskom materijalu (u kojem uz pristanak

3 Autori će u radu koristi pojam cyber dosljedno navedenim relevantnim znanstvenim izvorima na predmetnom području

4 Primjerice u pojmovima kiber-kriminala i kiber-prostora 
sudjeluju punoljetne osobe). Naglašavamo kako se ne smije zanemariti važnost ispravne definicije samog pojma, s obzirom na to da riječ pornografija podrazumijeva pristanak koji u slučaju dječje pornografije, odnosno seksualnog iskorištavanja djece ne postoji. Unatoč tome, većina zemalja u svojim zakonskim odredbama još uvijek definira ovo područje kao dječju pornografiju na internetu, iako se stručnjaci i praktičari te relevantne međunarodne organizacije (The European Union Agency for Law Enforcement Cooperation [EUROPOL], 2019), zalažu za korištenje konvencijskog jezika i termina seksualnog zlostavljanja i iskorištavanja djece na internetu. $U$ domaćim okvirima, termini "seksualno zlostavljanje" i "iskorištavanje djece na internetu" adekvatno se koriste u djelovanjima pojedinih neprofitnih organizacija i javnih tijela (http://cnzd.org/edukacija, Ministarstvo unutarnjih poslova [MUP], 2020).

lako autori ovog rada podržavaju suvremene trendove s ciljem jasnog definiranja područja seksualnog iskorištavanja djece u digitalnom okruženju, u pojedinim dijelovima teksta će se ipak koristi termin dječje pornografije, prvenstveno imajući u vidu važeće zakonske odredbe i uvriježenu normativnu terminologiju.

\section{Definiranje nasilja, zlostavljanja i iskorištavanja djece na internetu}

Elektroničko nasilje i zlostavljanje najčešće se izučava u kontekstu djece i mladih (Menesini i Nocentini, 2009). lako je zlostavljanje i nasilje na internetu nad i među djecom i mladima u fokusu istraživača, stručnjaka pa i same javnosti, Patchuin i Hindua (2015) navode kako još uvijek nema konsenzusa autora o definicijama i načinima mjerenja navedene pojave. Postoji nekoliko različitih definicija nasilja i zlostavljanja putem modernih tehnologija.

Najšire gledano cyber nasilje(cyber violence) je svako ponašanje putem modernih tehnologija u kojem komunikacija između pojedinaca ili skupina uključuje poruke agresivnoga ili neprijateljskog karaktera koje su namijenjene nanošenju neugode ili povrede drugim osobama (Tokunaga, 2010).

Holt (2011) cyber nasilje definira kao distribuciju štetnih ili opasnih materijala na mreži, koja pojedincu nanose emocionalnu štetu ili nasilje koje uključuje distribuciju materijala preko interneta koji se mogu iskoristiti kako bi osobu povrijedili u stvarnom svijetu ili online okruženju. Ovaj oblik se većinom izučava i veže uz nasilje među djecom i mladima, odnosno tzv. vršnjačko nasilje (eng. peer violence)(Peterson i Densley, 2017; Velki i Vrdoljak, 2013).

S druge stane cyber zlostavljanje (eng. cyber abuse) se koristi kao krovni pojam koji obuhvaća širok spektar štetnih aktivnosti poput elektroničkog zlostavljanja među djecom (eng. cyberbullying), uznemiravanja i prijetnji putem interneta (eng. cyber harassment, cyber threats), uhođenja putem interneta (eng. cyberstalking) te seksualnog zlostavljanja i iskorištavanja djece (eng. child sexual abuse ili CSA i child sexual exploitation ili CSE) na internetu koji će biti definirani u nastavku (Altobelli, 2010; Schell i Martin, 2004). Također, važno je istaknuti da počinitelj zlostavljanja na internetu može biti vršnjak ili odrasla osoba (Mishna, Cook, Saini, Wu i MacFadden, 2009). Elektroničko zlostavljanje uključuje radnje koje su ponavljane, namjerne, štetne i odvijaju se u odnosima u kojima postoji neravnoteža moći (Patchin, 2015). Shodno tome, usporedimo li cyber zlostavljanje (eng. cyber abuse) sa cyber nasiljem (eng. cyber violence), zlostavljanje je teži i ozbiljniji oblik štetnog ponašanja u virtualnom okruženju. lako se elektroničko zlostavljanje najčešće izučava u području 
vršnjačkih odnosa, važno je naglasiti kako viktimizaciju na internetu dijete može doživljavati i od strane odraslog počinitelja.

Pojam zlostavljanja u cyber okruženju ili stvarnom svijetu bi se trebao kritički koristiti5 u slučajevima kada nasilno ponašanje sadrži sve navedene elemente koji omogućuju klasifikaciju takvog ponašanja kao zlostavljanja (Vejmelka, 2012). Ključne specifičnosti zlostavljanja putem interneta uključuju neravnotežu moći u smislu posjedovanja određenih sadržaja poput podataka, slika i videa te superiornosti počinitelja u digitalnim kompetencijama i mogućnosti "anonimnog" djelovanja (Shariff i Gouin, 2006; Vandebosch i Van Cleemput, 2008). Bitno je reći kako je u virtualnom svijetu ponavljanje nasilničkih situacija i ponavljano viktimiziranje neizbježno i kod samo jednog nasilnog događaja zbog same naravi virtualnog svijeta (Vejmelka, Strabić i Jazvo, 2017).

Seksualno zlostavljanje djece na internetu (eng. online child sexual abuse) jedan je od najtežih oblika zlostavljanja djeteta u digitalnom okruženju, a uključuje bilo koji oblik seksualnog zlostavljanja djece (CSA) koji ima poveznicu s mrežnim okruženjem. Seksualno iskorištavanje djece na internetu (eng. online child sexual exploitation) je oblik seksualnog iskorištavanja djece koje se događa kada pojedinac ili grupa iskoriste neravnotežu moći da bi prisilili, manipulirali ili prevarili dijete na seksualnu aktivnost putem virtualnog okruženja (http://luxembourgguidelines.org/). U ovom slučaju dijete može biti seksualno iskorišteno čak i ako se seksualna aktivnost činila sporazumnom. Dodatno se naglašava kako fizički kontakt nije presudan, već se seksualno iskorištavanje djece (CSE) može dogoditi putem modernih tehnologija. Seksualno iskorištavanje djece može ići u dva smjera (1) seksualna aktivnost u zamjenu za nešto što dijete treba ili želi i (2) u svrhu ostvarivanja financijske koristi ili pribavljanja statusa počinitelja (Department for Education, 2017). Ovaj oblik seksualnog iskorištavanja djece se naziva i komercijalno seksualno iskorištavanje djece (eng. commercial sexual exploitation of children), pojam koji se odnosi na niz zločina i aktivnosti koje uključuju seksualno zlostavljanje ili iskorištavanje djeteta radi financijske koristi bilo koje osobe ili u zamjenu za bilo što vrijedno (uključujući novčane i nenovčane koristi) primljene od bilo koje osobe (Office of Juvenile Justice and Delinquency Prevention[OJJDP], 2018).

Seksualno zlostavljanje djece u širem smislu uključuje sve oblike seksualnog iskorištavanja i seksualnog zlostavljanja djece na internetu. Prilikom ovih oblika zlostavljanja djece na internetu, produciraju se, distribuiraju i koriste materijali seksualnog zlostavljanja i iskorištavanja djece (CSAM: child sexual abuse material, CSEM: child sexual exploitation material). Suvremeni trendovi seksualnog iskorištavanja djece na internetu uključuju zlouporabu onih materijala koja su djeca sama producirala i podijelila putem modernih tehnologija (eng. self-generated explicit material ili SGEM)(http:// luxembourgguidelines.org/). Seksualno zlostavljanje djece u stvarnom svijetu, kao i na internetu, izdvaja se kao posebna kategorija zlostavljanja djece koja ostavlja dugotrajne i teške posljedice na žrtvu i negativno utječe na adekvatni psihosocijalni razvoj djeteta (Davidson, Grove-Hills, Bifulco, Gottschal, Caretti, Pham i Webster, 2011; ECPAT, 2018). Dakle, elektroničko nasilje, elektroničko zlostavljanje, seksualno zlostavljanje i seksualno iskorištavanje djece na internetu nisu istoznačni pojmovi te ih je s obzirom na to potrebno adekvatno koristiti u znanstveno-stručnom diskursu kao i prilikom planiranja istraživačkih nacrta te izvještavanja o rezultatima istih.

5 Šira rasprava o razlikama elektroničkog nasilja i zlostavljanja među djecom i mladima dostupna je u radu Vejmelke, Strabić i Jazvo (2017) gdje se navodi da se svako nasilničko ponašanje u virtualnom okruženju ne može kategorizirati kao zlostavljanje. 


\section{Vrbovanje djeteta u spolne svrhe putem interneta}

Spomenimo i definiciju vrbovanja djeteta u spolne svrhe putem interneta (online grooming) obzirom da je ovaj pojam usko vezan uz online seksualno zlostavljanje i iskorištavanje djeteta te je inkriminiran u domaćem kaznenom zakonodavstvu, o čemu će biti riječ nešto kasnije. Vrbovanje djeteta u spolne svrhe ili takozvani spolni grooming predstavlja proces kojim se zlostavljač koristeći različite manipulativne strategije nastoji približiti te uspostaviti odnos s potencijalnom žrtvom (u ovom slučaju djetetom), ne bi li zadobio njezino povjerenje te ju naposljetku potaknuo na određenu spolnu radnju (Craven, Brown i Gilchrist, 2006). U skladu s navedenim, pojam takozvanog online groominga odnosno spolnog vrbovanja upotrebom informacijsko komunikacijske tehnologije definiran je kao spolno iskorištavanje djece u kibernetičkom prostoru i to posebice putem socijalnih mreža i sličnih platformi, s krajnjom namjerom spolnog ili online zlostavljanja djeteta ili pak proizvodnje dječje pornografije (Škrtić, 2013). Upravo virtualno okruženje daje jednu novu dimenziju vrbovanju djece, omogućivši počiniteljima da lakše pristupe potencijalnim žrtvama, istovremeno zadržavajući višu razinu anonimnosti prilikom činjenja ovakvih kaznenih djela. U nastavku slijedi sažeti prikaz normativnog okvira seksualnog iskorištavanja djece na internetu u domaćem zakonodavstvu te prikaz nacionalnih statističkih pokazatelja na ovom području.

\section{SEKSUALNO ZLOSTAVLJANJE I ISKORIŠTAVANJE DJECE U HRVATSKOJ: PRAVNO UREĐENJE I STATISTIČKI POKAZATELJI}

Globalni karakter interneta, dostupnost sadržaja te brzina i jednostavnost razmjene informacija doveli su do toga da seksualno zlostavljanje i iskorištavanje djece na internetu postaje globalni problem za čije je uspješnije rješavanje nužna međunarodna državna suradnja (Gillespie, 2010). U trenutku kada nacionalne politike više nisu mogle odgovoriti na bujanje protupravnih postupanja na internetu, javila se potreba donošenja međunarodnih instrumenata kako bi se mogli zaštititi najranjiviji članovi društva, odnosno djeca. U većini zemalja pa tako i u Hrvatskoj, uvriježena pravna i stručna praksa služi se terminologijom dječje pornografije na način da se u zakonskim odredbama propisuje iskorištavanje djece za pornografske svrhe.

\section{Međunarodni standardi zaštite zlostavljanja i iskorištavanja djece na internetu}

Kao najvažnije međunarodne dokumente u kaznenopravnoj zaštiti djece od iskorištavanja u svrhe pornografije, potrebno je spomenuti Konvenciju o pravima djeteta usvojenu 20. studenog 1989. godine te Fakultativni protokol uz Konvenciju o pravima djeteta o prodaji djece, dječjoj prostituciji i pornografiji te zabrani sudjelovanja djece u oružanim sukobima, Konvenciju Vijeća Europe o kibernetičkom kriminalu kojom je po prvi puta dana zakonska definicija kaznenog djela dječje pornografije, Konvenciju o zaštiti djece od seksualnog iskorištavanja i seksualnog zlostavljanja usvojenu od strane Europskog parlamenta i Vijeća Europe 2007. godine poznatu kao "Lanzarote konvencija" te Direktivu o suzbijanju seksualnog zlostavljanja i seksualnog iskorištavanja djece i dječje pornografije kojom se zemlje članice Europske unije obvezuju na donošenje preventivnih mjera i zaštitu djece žrtava. Unatoč razlikama u definiranju samog pojma dječje pornografije, svaki od navedenih međunarodnih dokumenata naglasak stavlja na materijal koji vizualno prikazuje 
dijete/maloljetnika u seksualno eksplicitnom činu. Navedene međunarodne konvencije i direktive imale su velik utjecaj na razvoj nacionalnih zakonodavstva država koje su ih ratificirale.

\section{Pravno uređenje spolnog zlostavljanja i iskorištavanja djeteta u Hrvatskoj}

U Hrvatskoj su novim Kaznenim zakonom iz 2011. godine, pod utjecajem navedenih međunarodnih standarda, reformirana djela spolnog iskorištavanja djece na način da su proširene inkriminacije djela zlostavljanja i iskorištavanja djece te su propisane povećane kazne zatvora za počinitelje ovih kaznenih djela. Kaznena djela spolnog zlostavljanja i iskorištavanja djeteta su navedenim zakonskim izmjenama smještena u odvojenu, glavu XVII Kaznenog zakona. U ovoj glavi su, uz ostala kaznena djela na štetu djece, uključeni članci zakona koji se odnose na iskorištavanje djece za pornografske sadržaje (čl 163., čl 164., čl. 165.). Republika Hrvatska kao država potpisnica obje konvencije, u svojem Kaznenom zakonu inkriminirala je djela spolnog zlostavljanja i iskorištavanja djeteta na internetu na način da je u članku 163. Kaznenog zakona kao kazneno djelo propisano iskorištavanje djece za pornografiju, u članku 164. iskorištavanje djece za pornografske predstave te $u$ članku 165. upoznavanje djece s pornografijom. U ovim zakonskim odredbama informacijske komunikacijske tehnologije su izrijekom navedene kao moguće sredstvo počinjenja kaznenog djela te je propisano oduzimanje računalne opreme, programa i podataka uz obvezu uništavanja pornografskog materijala koji je nastao počinjenjem navedenih kaznenih djela.

Šira inkriminacija kaznenih djela zlostavljanja i iskorištavanja djece uključuje i mamljenje djece za zadovoljenje spolnih potreba u članku 161. kaznenog zakona, gdje je u prvom stavku navedeno kako će se kaznom zatvora od 6 mjeseci do 5 godina kazniti punoljetna osoba koja osobi mlađoj od petnaest godina, u namjeri da ona ili druga osoba nad njom počini kazneno djelo spolne zlouporabe djeteta mlađeg od 15 godina, kazneno djelo iskorištavanja djece za pornografiju ili pak iskorištavanja djece za pornografske predstave, putem informacijsko komunikacijskih tehnologija ili na drugi način predloži susret s njom ili drugom osobom ikoja poduzme mjere da do tog susreta dođe. Ovom odredbom zakonodavac prvi puta u domaćim okvirima propisuje inkriminiranje mamljenja djece u spolne svrhe.

lako Hrvatska, kao i većina ostalih država, u pravnom uređenju u potpunosti ne koristi suvremenu terminologiju u području seksualnog zlostavljanja i iskorištavanja djece, propisi su usklađeni s relevantnim međunarodnim dokumentima i standardima u području suzbijanja seksualnog zlostavljanja i iskorištavanja djece na internetu.

\section{Nacionalni statistički pokazatelji kaznenih djela spolnog zlostavljanja i iskorištavanja djeteta na internetu}

Cyber zločini u prošlosti često nisu imali uporište u zakonodavstvu niti zakonsku referencu konkretnog kaznenog djela, već su se sustavno svodili na neki od definiranih tradicionalnih oblika pa je pojam cyber zločina bio široko korišten, dok istovremeno nije bio znanstveno ni praktično prepoznat (Wall, 2004, 2015). S druge strane, suvremeni trendovi na ovom području u međunarodnim i domaćim okvirima pokazuju napore u smjeru revidiranja i dopunjavanja zakonskih odredbi, o čemu je bilo riječ i u prethodnim poglavljima. Naime, potrebno je naglasiti kako je svaki nacionalni kazneni sustav određen posebnostima koje se odražavaju i na područje normiranja ovih kaznenih djela, 
stoga zaključke navedene na početku ovog poglavlja nije moguće generalizirati na kazneno-pravna uređenja svih zemalja. Izmjene u zakonskim odredbama prate i promjene u prikupljanju i prikazu statističkih pokazatelja. Poteškoće prilikom praćenja trendova spolnog zlostavljanja i iskorištavanja djece na internetu prisutne su zbog neujednačenih statističkih pokazatelja, različitih metodologija praćenja fenomena kao i zbog promjena u samom načinu prikaza podataka. Na ovom području u domaćim okvirima relevantni su pokazatelji javnih tijela poput Ministarstva unutarnjih poslova i Ministarstva pravosuđa te godišnji statistički pokazatelji koje objavljuje Državni zavod za statistiku, a koji će biti pobliže predstavljeni u nastavku rada.

Dostupni statistički podaci Ministarstva unutarnjih poslova do 2017. godine nisu razlikovali online oblik dječje pornografije, već se izvještavalo o kaznenim djelima protiv spolne slobode i spolnog zlostavljanja i iskorištavanja djeteta, gdje su dostupni podaci za sve počinitelje kaznenih djela dječje pornografije (MUP, 2017). Od 2017. godine se o kaznenim djelima dječje pornografije na internetu u službenim statistikama izvještava u području kibernetičkog kriminaliteta, gdje su uz dječju pornografiju na internetu (čl. 163. stavak 2.) navedena i ostala kaznena djela iz područja cyber kriminala (MUP, 2018).

Nacionalni statistički pokazatelji dostupni na razini Državnog zavoda za statistiku (Grafički prikaz 1. i Grafički prikaz 2.) od 2013. do 2018. godine potvrđuju porast kaznenih djela spolnog zlostavljanja i iskorištavanja djeteta koja se odvijaju u digitalnom okruženju kod obje skupine, punoljetnih i maloljetnih počinitelja što je u skladu s međunarodnim trendovima (EUROPOL, 2019). Ovo se vjerojatno može pripisati napretku suvremenih programskih metoda otkrivanja počinitelja na internetu te međunarodnoj umreženosti u ovom području, ali i većoj izloženosti djece i olakšanoj dostupnosti njihovih osobnih podataka počiniteljima, obzirom na porast broja korisnika interneta u svim dobnim skupinama.

6 Kako su statistički podaci prikazani na ovaj način za sada dostupni samo za 2017. (140 prijavljenih kaznenih djela iskorištavanja djece za pornografiju domeni kibernetičkog kriminaliteta) i 2018. (55 prijavljenih kaznenih djela iz iste skupine) godinu, nije moguće govoriti o trendovima kretanja seksualnog iskorištavanja djece na internetu na području Republike Hrvatske, posebice ako znamo da je broj kaznenih djela iz područja kibernetičkog kriminaliteta u 2019. porasla za 28,3\%, iako još uvijek nisu objavljeni podaci o pojedinačnim oblicima unutar ove kategorije delikata (MUP, 2019). 


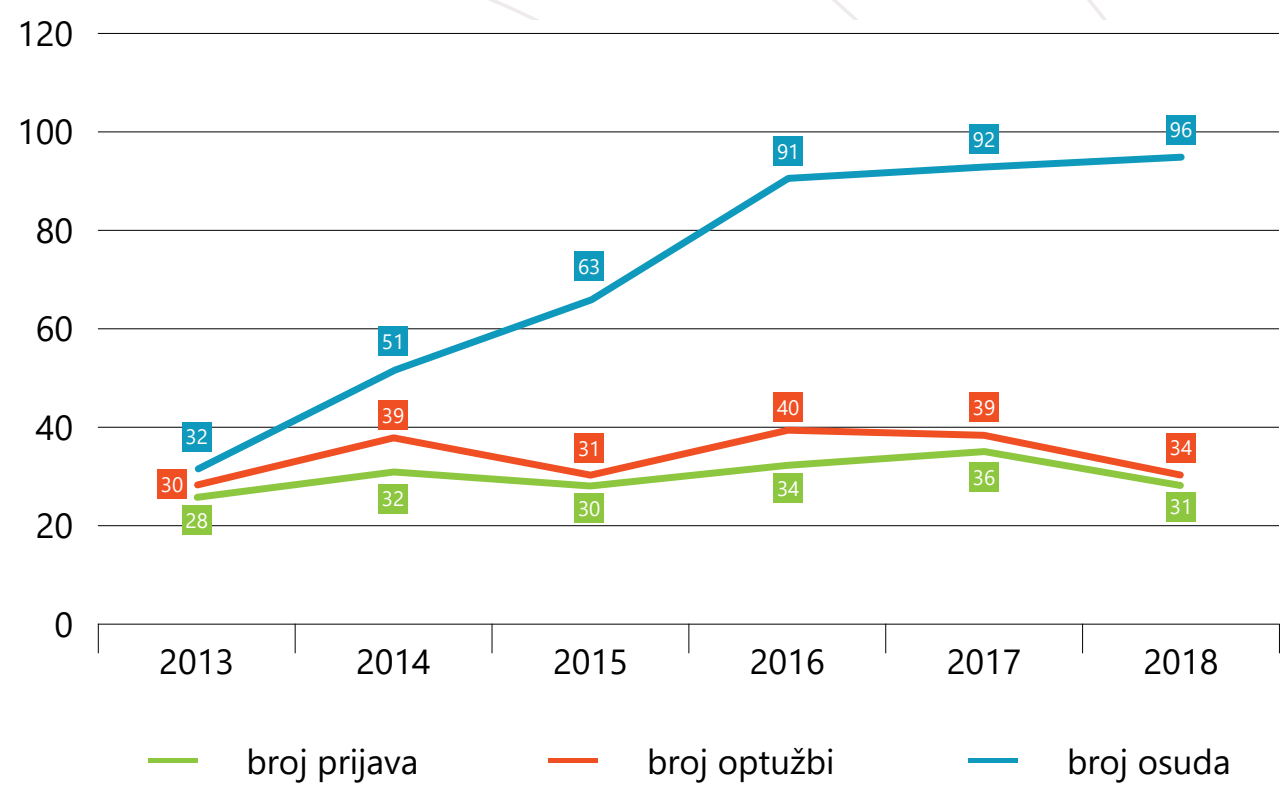

Grafički prikaz 1. Prijavljene, optužene i osuđene punoljetne osobe za kaznena djela seksualnog zlostavljanja i iskorištavanja djece na internetu (DZS, 2013, 2014, 2015, 2016, 2017, 2018)

Kako je vidljivo iz grafičkog prikaza 1, broj prijava raste, no nema i proporcionalnog rasta broja optuženih i osuđenih počinitelja. Važno je naglasiti kako su na ovom području evidentne različite prakse kažnjavanja počinitelja seksualnih delikata na štetu djece, što je i očekivano s obzirom na postavljenje raspone zatvorskih sankcija koje omogućavaju sudskoj praksi donošenje diskrecijske ocjene prilikom određivanja primjerene kazne temeljene na objektivnim i subjektivnim okolnostima slučaja. Nalazi istraživanja o pravosudnoj praksi unutar područja dječje pornografije na internetu i počinitelja u sustavu probacije Ministarstva pokazuju da se za kaznena djela iskorištavanja i zlostavljanja djece putem interneta, u pravilu izriču kazne bliže zakonskom minimumu ili pak štoviše mjere poput rada za opće dobro, iako Kazneni zakon naglašava i propisuje teže sankcije ističući na taj način ozbiljnost i težinu ovih kaznenih djela (Vejmelka, Brkić i Radat, 2017). S druge strane, potrebno je naglasiti da je obzirom na djelokrug rada probacijske službe koja postupa u izvršenju rada za opće dobro te ostalih posebnih obveza i sigurnosnih mjera, u navedenom istraživanju bilo prisutno ograničenje uvrštavanja težih i najtežih predmeta po načinu počinjenja i kriminološkoj i viktimološkoj supstanci što je imalo utjecaja na krajnje rezultate. Ritossa (2018) nalazi kako su najveća odstupanja u strategiji izbora vrste i mjere sankcije sudova uočena upravo kod izricanja bezuvjetne kazne zatvora od 6 do 12 mjeseci za počinitelja seksualnih delikata na štetu djece. No za ozbiljnija zaključivanja i procjene uspješnosti izrečenih sankcija potrebne su sustavne znanstvene analize koje bi uključile prikupljanje različitih pokazatelja o vrsti i kontekstu počinjenja ovih kaznenih djela, daljnjem recidivu osuđenih počinitelja, a ukoliko je do recidiva i došlo, o njegovoj vrsti i etiološkim razlozima. 


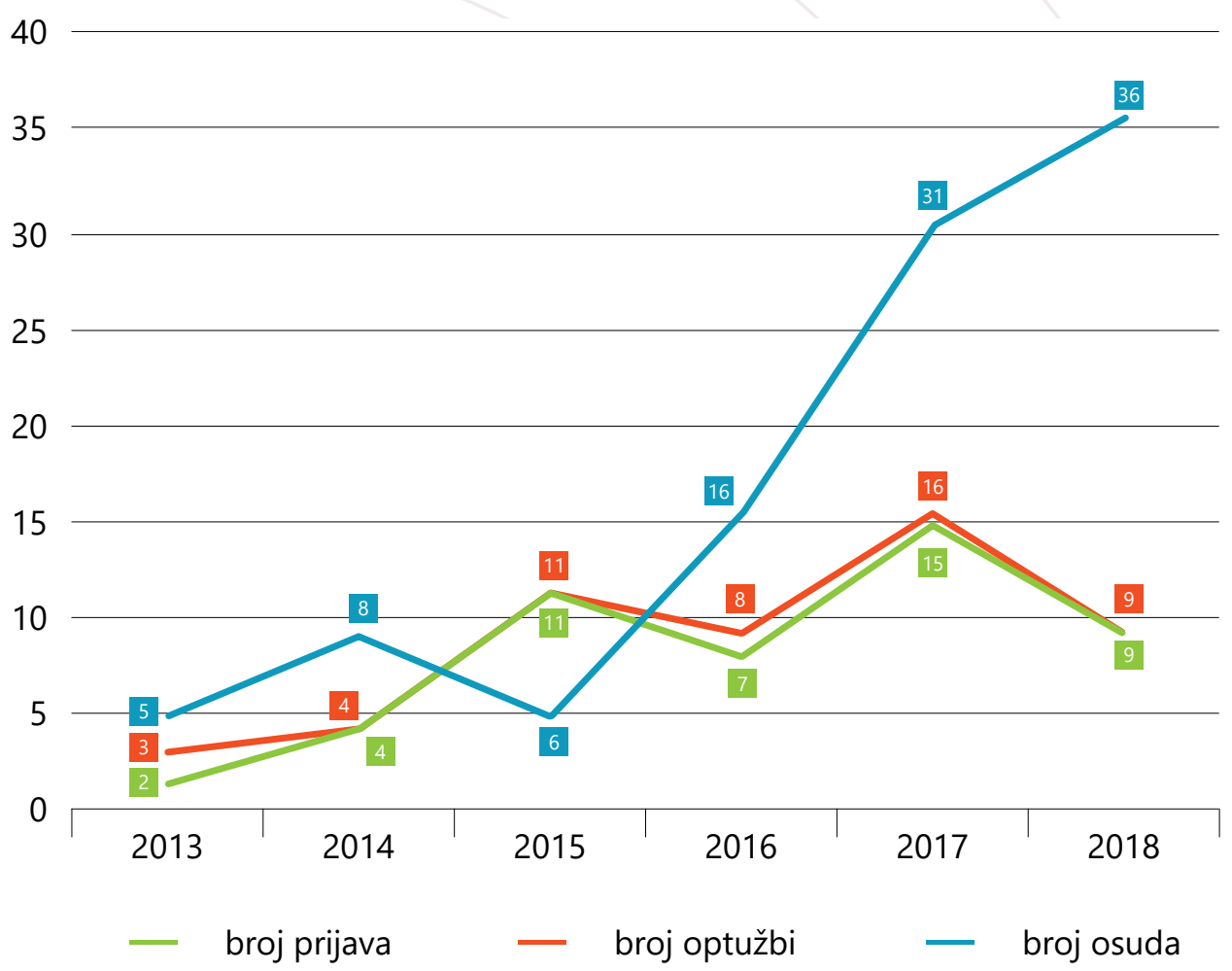

Grafički prikaz 2. Prijavljene, optužene i osuđene maloljetne osobe za kaznena djela spolnog zlostavljanja i iskorištavanja djeteta djece na internetu (DZS, 2013, 2014, 2015, 2016, 2017, 2018)

No u vidu prikladnosti normiranja pojedinih kaznenih djela iz područja spolnog zlostavljanja i iskorištavanja djeteta na internetu, zanimljivo je da je u promatranom razdoblju bilo samo 5 prijava, 1 optužba i niti jedna osuda za kazneno djelo po članku 164. Kaznenog zakona koji propisuje iskorištavanje djece za pornografske predstave. Potrebno je naglasiti kako se riječ predstava u našem jeziku koristi za izvedbu scenskog djela ${ }^{7}$ što također nije moguće dovesti u vezu sa seksualnim iskorištavanjem djeteta na internetu. Taj termin nije uvriježen u znanstvenom diskursu ni stručnoj praksi, a s obzirom na upravo navedene statističke pokazatelj niti prepoznat u kaznenopravnoj praksi.

Tablica 1. Prijavljeni, optuženi i osuđeni počinitelji u razdoblju od 2013. do 2018. godine (www. dzs.hr)

\begin{tabular}{|c|c|c|c|c|}
\hline \multirow[b]{3}{*}{ GODINA } & \multirow[b]{3}{*}{ POČINITELJI } & \multicolumn{3}{|c|}{ Kaznena djela spolnog zlostavljanja i iskorištavanja djeteta na internetu } \\
\hline & & \multicolumn{3}{|c|}{ čl. 161} \\
\hline & & broj prijava & broj optužbi & broj osuda \\
\hline \multirow{2}{*}{2018.} & PUNOLJETNI & 4 & 5 & 4 \\
\hline & MALOLJETNI & - & - & - \\
\hline \multirow{2}{*}{2017.} & PUNOLJETNI & 5 & 3 & 3 \\
\hline & MALOLJETNI & - & - & - \\
\hline \multirow{2}{*}{2016.} & PUNOLJETNI & 9 & - & - \\
\hline & MALOLJETNI & - & - & - \\
\hline \multirow{2}{*}{2015.} & PUNOLJETNI & 8 & - & - \\
\hline & MALOLJETNI & 1 & - & - \\
\hline \multirow{2}{*}{2014.} & PUNOLJETNI & 1 & 3 & 3 \\
\hline & MALOLJETNI & - & - & - \\
\hline \multirow{2}{*}{2013.} & PUNOLJETNI & 5 & - & - \\
\hline & MALOLJETNI & - & - & - \\
\hline
\end{tabular}




\begin{tabular}{|c|c|c|c|c|c|c|c|c|c|c|}
\hline \multirow[b]{3}{*}{ GODINA } & \multirow[b]{3}{*}{ POČINITELJI } & \multicolumn{9}{|c|}{ Kaznena djela spolnog zlostavljanja i iskorištavanja djeteta na internetu } \\
\hline & & \multicolumn{9}{|c|}{ čl. 163} \\
\hline & & $\begin{array}{c}\text { st.1 } \\
\text { broj } \\
\text { prijava }\end{array}$ & $\begin{array}{c}\text { st.1 } \\
\text { broj } \\
\text { optužbi }\end{array}$ & $\begin{array}{c}\text { st.1 } \\
\text { broj } \\
\text { osuda }\end{array}$ & $\begin{array}{c}\text { st.2 } \\
\text { broj } \\
\text { prijava }\end{array}$ & $\begin{array}{c}\text { st.2 } \\
\text { broj } \\
\text { optužbi }\end{array}$ & $\begin{array}{c}\text { st.2 } \\
\text { broj } \\
\text { osuda }\end{array}$ & $\begin{array}{c}\text { st.3 } \\
\text { broj } \\
\text { prijava }\end{array}$ & $\begin{array}{c}\text { st.3 } \\
\text { broj } \\
\text { optužbi }\end{array}$ & $\begin{array}{c}\text { St.3 } \\
\text { broj } \\
\text { osuda }\end{array}$ \\
\hline \multirow{2}{*}{2018.} & PUNOLJETNI & 28 & 14 & 13 & 34 & 10 & 9 & 4 & 1 & 1 \\
\hline & MALOLJETNI & 4 & 2 & 2 & 29 & 7 & 7 & 1 & - & - \\
\hline \multirow{2}{*}{2017.} & PUNOLJETNI & 25 & 17 & 16 & 40 & 11 & 10 & 8 & 2 & 2 \\
\hline & MALOLJETNI & 5 & 5 & 4 & 18 & 7 & 7 & 1 & 4 & 4 \\
\hline \multirow{2}{*}{2016.} & PUNOLJETNI & 28 & 15 & 14 & 29 & 19 & 18 & 7 & 1 & 1 \\
\hline & MALOLJETNI & 4 & - & - & 10 & 7 & 6 & 1 & 1 & 1 \\
\hline \multirow{2}{*}{2015.} & PUNOLJETNI & 13 & 14 & 14 & 32 & 9 & 9 & 1 & 1 & 1 \\
\hline & MALOLJETNI & 1 & 1 & 1 & 4 & 10 & 10 & - & - & - \\
\hline \multirow{2}{*}{2014.} & PUNOLJETNI & 9 & 9 & 7 & 19 & 17 & 17 & 1 & - & - \\
\hline & MALOLJETNI & - & 1 & 1 & 8 & 3 & 3 & - & - & - \\
\hline \multirow{2}{*}{2013.} & PUNOLJETNI & - & 9 & 8 & 6 & 10 & 10 & 15 & - & - \\
\hline & MALOLJETNI & - & - & - & 3 & 1 & 1 & 1 & - & - \\
\hline
\end{tabular}

\begin{tabular}{|c|c|c|c|c|}
\cline { 3 - 4 } \multicolumn{2}{c|}{} & \multicolumn{2}{c|}{ Kaznena djela spolnog zlostavljanja i iskorištavanja djeteta na internetu } \\
\cline { 3 - 5 } \multicolumn{2}{c|}{} & \multicolumn{2}{c|}{ čl. 165 st. 1} \\
\hline \multirow{2}{*}{ GODINA } & POČINITELJI & broj prijava & broj optužbi & broj osuda \\
\hline \multirow{2}{*}{2018.} & PUNOLJETNI & 25 & 4 & 4 \\
\cline { 2 - 5 } & MALOLJETNI & 2 & - & - \\
\hline \multirow{2}{*}{2017.} & PUNOLJETNI & 13 & 6 & 5 \\
\cline { 2 - 5 } & MALOLJETNI & 7 & - & - \\
\hline \multirow{2}{*}{2016.} & PUNOLJETNI & 17 & 5 & - \\
\cline { 2 - 5 } & MALOLJETNI & 1 & - & - \\
\hline \multirow{2}{*}{2015.} & PUNOLJETNI & 8 & 6 & 5 \\
\cline { 2 - 5 } & MALOLJETNI & - & - & - \\
\hline \multirow{2}{*}{2014.} & PUNOLJETNI & 21 & 10 & 10 \\
\cline { 2 - 5 } & MALOLJETNI & - & - & 2 \\
\hline \multirow{2}{*}{2013.} & PUNOLJETNI & 5 & 11 & \\
\cline { 2 - 5 } & MALOLJETNI & 1 & 2 & - \\
\hline
\end{tabular}

U Tablici 1 navedeni su brojevi prijava, optužbi i osuda za maloljetne i punoljetne počinitelje za razdoblje od 2013. do 2018. godine. Statistički podaci pokazuju kako se većina prijava te optužbi i osuda ovih kaznenih djela odnosi na članak 163. Kaznenog zakona. Brojčani pokazatelji potvrđuju već naglašene nerazmjere u broju prijavljenih, osuđenih i optuženih počinitelja što bi bilo korisno dodatno ispitati u budućim istraživanjima, posebice onima koja bi se bavila istraživanjem razloga većeg broja prijavljenih u odnosu na broj optuženih i osuđenih počinitelja kaznenih djela spolnog zlostavljanja i iskorištavanja djeteta na internetu. Nadalje, važno je naglasiti kako jedan dio kaznenih djela u navedenom području počine sami maloljetnici pa u ukupnom broju počinitelja ovih kaznenih djela njihov udio varira od 10 do $37,5 \%$ ovisno o promatranom razdoblju, što svakako treba uzeti u obzir prilikom planiranja i provođenja sankcija i mjera sa ovom skupinom identificiranih počinitelja.Zaključno, kontinuirano praćenje statističkih podataka uz adekvatno izvještavanje o ovim kaznenim djelima osnova je za sustavan pregled pojave seksualnog zlostavljanja i iskorištavanja 
djece na internetu i planiranje koordiniranih aktivnosti s ciljem suzbijanja ovih kaznenih djela na štetu djece u digitalnom okruženju.

\section{ZAKLJUČNA RAZMATRANJA}

Kako bismo sustavnije zaštitili djecu od seksualnog zlostavljanja i iskorištavanja, ključno je razumjeti i razgraničiti termine kojima se služimo u ovom području. U skladu s tim suvremeni trendovi nalažu potrebu jasnijeg konceptualiziranja i usuglašavanja oko definicija, kako među različitim državama tako i unutar njih. lako su u domaćem kontekstu zakonski okviri u području seksualnog iskorištavanja na internetu u skladu s međunarodnim standardima, kada govorimo o zaštiti djece u ovom području, izostaje jasno definiranje ovog pojma u praktičnom djelovanju. Naime, razlike u definicijama onoga što zapravo predstavlja materijal seksualnog iskorištavanja djece na internetu rezultiralo je time da su različite jurisdikcije posegnule za različitim tumačenjima inkriminacija i s tim povezanim kaznama pa tako u nekim državama počinitelj seksualnog iskorištavanja djece na internetu može dobiti 3 do 4 godine zatvora dok u drugim sustavima može dobiti i doživotnu kaznu. Dakle, nedostatak jasne konceptualizacije pojavnih oblika seksualne viktimizacije djece na internetu, uz ostale neusklađene elemente (poput dobi pristanka na seksualni odnos, oblika i sadržaja kaznenog djela i sl.) može imati i ima utjecaj na različito zakonsko reguliranje ovog kaznenog djela u različitim sustavima (Schell, Martin, Hung i Rueda, 2007). ${ }^{8}$ No potrebno je naglasiti kako je zakonodavac u svakom kaznenopravnom nacionalnom sustavu taj koji donosi odluke kojima gradi zakonski nacionalni sustav, kroz usvajanje pojedinih zakonskih normi u okviru svojih ustavnih zadaća pa je očekivano da će se kaznenopravna uređenja pojedinih kaznena djela spolnog zlostavljanja i iskorištavanja djece razlikovati od zemlje do zemlje.

Također, adekvatna terminologija i definiranje ovog područja, za koju se zalažu brojne relevantne međunarodne organizacije, omogućilo bi primjerenije praćenje ove pojave u međunarodnim okvirima. Predmet ovog rada može biti zanimljiv i praktičarima u smislu osvještavanja važnosti razumijevanja termina kojima se služimo u području seksualne viktimizacije djece. Iz navedenih razloga važno je pokretanje šire znanstveno-stručne rasprave te jasno definiranje područja seksualnog iskorištavanja djece u digitalnom okruženju, sukladno terminološkim smjernicama, na način koji bi omogućio jasno iskazivanje i praćenje oblika seksualnog iskorištavanja djece na internetu te olakšao praćenje trendove počinjenja ovih kaznenih djela. Potrebno je naglasiti kako je potrebno da stručnjaci koji djeluju na ovom području, unatoč terminološkoj neusklađenosti zakonskih odredbi, imaju mogućnost koristiti primjerenu terminologiju u edukaciji i prevenciji. Jasno definiranje termina od iznimne je važnosti za prikupljanje i obradu podataka, utvrđivanje trendova te samim time kreiranje preventivnih i edukativnih programa. No, to ne isključuje važnost promišljanja i analiziranja terminoloških propusta u postojećim zakonskim rješenjima te poticanje zakonodavca na konkretne izmjene i dopune kaznenih djela u svezi s pornografskim sadržajem, a počinjenih na štetu djece. Doprinos ovog rada ogleda se upravo u približavanju i ispravnom definiranju ključnih pojmova i koncepata unutar predmetnog područja, kreirajući tako terminološku podlogu/osnovu koja može koristiti svim akterima koji djeluju unutar područja zaštite djece i prevencije njihovog zlostavljanja i iskorištavanja u online okruženju.

8 Snažan pokušaj uniformnog reguliranja tih kaznenih djela u zemljama članicama EU predstavlja Direktiva 2011/93/EU 
U domaćim okvirima potrebno je pohvaliti ciljane napore, u tekstu navedenih neprofitnih organizacija te državnih tijela koji kontinuirano promiču upotrebu konvencijskog jezika i prikladne terminologije te unapređenje vođenja statistike čime aktivno djeluju na području osvještavanja težine i ozbiljnosti ovih kaznenih djela, zalažući se istovremeno za adekvatno praćenje, identificiranje i sankcioniranje počinitelja. U ovom radu nisu obuhvaćeni izazovi suradnje među organizacijama i državnim tijelima, no važno je naglasiti kako kontinuirana suradnja među navedenim organizacijama i institucijama nerijetko izostaje, a ključna je za suzbijanje ovog fenomena. lako relevantni izvori navode, a međunarodni dokumenti obvezuju, kako je suradnja između akademskog, neprofitnog i javnog sektora u suzbijanju seksualnog iskorištavanja djece na internetu ključna, nažalost ona u domaćim okvirima još uvijek nije u potpunosti ostvarena, na što upozorava Europska komisija u svom službenom izvještaju iz 2019. godine (Europska komisija, 2019). Dakle, u domaćim okvirima postoji potreba uspostavljanja i održavanja multidisciplinarne i multisektorske suradnje svih relevantnih aktera na ovom području.

Zaključno, potrebno je naglasiti kako je ovo područje pod utjecajem ubrzanog razvoja modernih tehnologija koje svakodnevno omogućavaju razvijanje novih načina činjenja štetnih i kažnjivih aktivnosti s ciljem seksualnog iskorištavanja djeteta. lako s jedne strane tehnologija uzrokuje ekspanziju kažnjivih sadržaja, s druge strane ista omogućava organiziranu, međunarodno umreženu i sustavnu borbu protiv počinitelja ovog kaznenog djela, stoga stručnjaci već neko vrijeme zagovaraju korištenje suvremenih tehnoloških i programskih rješenja na ovom području (Schell i sur., 2007). U svakom slučaju, područje seksualnog iskorištavanja djece na internetu zahtjeva kontinuirane, koordinirane i transdisciplinarne napore relevantnih organizacija, stručnjaka, znanstvenika te tijela s javnim ovlastima, ali i medija i šire javnosti u smjeru jasnog konceptualiziranja ovog područja, a potom i u svim ostalim aktivnostima u svrhu zaštite djece, s krajnjim ciljem ostvarivanja njihove maksimalne dobrobiti u digitalnom okruženju.

\section{LITERATURA}

Akrap, G. (2019). Suvremeni sigurnosni izazovi i zaštita kritičnih infrastruktura. Strategos, 3(2), 37-49.

Altobelli, T. (2010). Cyber abuse - a new worldwide threat to children's rights. Family Court Review, 48(3), 459-481. doi: 10.1111/j.1744-1617.2010.01323.x

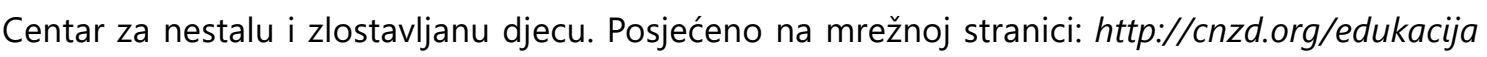
(18.01.2020.).

Corcoran, L., Guckin, C. M., \& Prentice, G. (2015). Cyberbullying or cyber aggression?: A review of existing definitions of cyber-based peer-to-peer aggression. Societies, 5(2), 245-255. doi: $10.3390 /$ soc5020245

Craven, S., Brown, S., \& Gilchrist, E. (2006). Sexual grooming of children: Review of literature and theoretical considerations. Journal of sexual aggression, 12(3), 287-299. doi: 10.1080/13552600601069414

Davidson, J., Grove-Hills, J., Bifulco, A., Gottschalk, P., Caretti, V., Pham, T., \& Webster, S. (2011). Online abuse: Literature review and policy context. Project Report European online grooming project. Posjećeno na mrežnoj stranici: http://citeseerx.ist.psu.edu/viewdoc/ download?doi=10.1.1.473.1618\&rep=rep1\&type $=p d f(12.01 .2020$.). 
Department for Education (2017). Child sexual exploitation: Definition and a guide for practitioners, local leaders and decision makers working to protect children from child sexual exploitation. Posjećeno na mrežnoj stranici: https://www.gov.uk/government/publications/ child-sexual-exploitation-definition-and-guide-for-practitioners (13.02.2020.).

Derenčinović, D. (2003). Dječja pornografija na Internetu - o kažnjivosti posjedovanja i virtualnoj dječjoj pornografiji. Hrvatski ljetopis za kazneno pravo i praksu, 10(1), 3-25.

Derenčinović, D. i Getoš, A. M. (2008). Uvod u kriminologiju s osnovama kaznenog prava. Zagreb: Pravni fakultet Sveučilišta u Zagrebu.

Direktiva Europskog parlamenta i Vijeća o suzbijanju seksualnog zlostavljanja i seksualnog iskorištavanja djece i dječje pornografije 2011/92. Posjećeno na mrežnoj stranici: https://eur-lex. europa.eu/legal-content/HR/TXT/?uri=celex\%3A32011L0093(22.11.2019.).

Državni zavod za statistiku (2020). Primjena informacijskih i komunikacijskih tehnologija (IKT) u kućanstvima i kod pojedinaca u 2019., 2020. Posjećeno na mrežnoj stranici: https:// www.dzs.hr/Hrv_Eng/publication/2019/02-03-02_01_2019.htm (12.01.2020.).

Državni zavod za statistiku, Godišnje statističko izvješće o maloljetnim počiniteljima kaznenih djela, prijavama, optužbama i osudama u 2013. Posjećeno na mrežnoj stranici: https://www. dzs.hr/Hrv_Eng/publication/2019/SI-1651.pdf (01.02.2020.).

Državni zavod za statistiku, Godišnje statističko izvješće o maloljetnim počiniteljima kaznenih djela, prijavama, optužbama i osudama u 2014. Posjećeno na mrežnoj stranici: https://www. dzs.hr/Hrv_Eng/publication/2019/SI-1651.pdf (01.02.2020.).

Državni zavod za statistiku, Godišnje statističko izvješće o maloljetnim počiniteljima kaznenih djela, prijavama, optužbama i osudama u 2015. Posjećeno na mrežnoj stranici: https://www. dzs.hr/Hrv_Eng/publication/2019/SI-1651.pdf (01.02.2020.).

Državni zavod za statistiku, Godišnje statističko izvješće o maloljetnim počiniteljima kaznenih djela, prijavama, optužbama i osudama u 2016. Posjećeno na mrežnoj stranici: https://www. dzs.hr/Hrv_Eng/publication/2019/SI-1651.pdf (01.02.2020.).

Državni zavod za statistiku, Godišnje statističko izvješće o maloljetnim počiniteljima kaznenih djela, prijavama, optužbama i osudama u 2017. Posjećeno na mrežnoj stranici: https://www. dzs.hr/Hrv_Eng/publication/2019/SI-1651.pdf (01.02.2020.).

Državni zavod za statistiku, Godišnje statističko izvješće o maloljetnim počiniteljima kaznenih djela, prijavama, optužbama i osudama u 2018. Posjećeno na mrežnoj stranici: https://www. dzs.hr/Hrv_Eng/publication/2019/SI-1651.pdf (01.02.2020.).

Državni zavod za statistiku, Godišnje statističko izvješće o punoljetnim počiniteljima kaznenih djela, prijavama, optužbama i osudama u 2013. Posjećeno na mrežnoj stranici: https://www. dzs.hr/ (01.02.2020.).

Državni zavod za statistiku, Godišnje statističko izvješće o punoljetnim počiniteljima kaznenih djela, prijavama, optužbama i osudama u 2014. Posjećeno na mrežnoj stranici: https://www. dzs.hr/ (01.02.2020.).

Državni zavod za statistiku, Godišnje statističko izvješće o punoljetnim počiniteljima kaznenih djela, prijavama, optužbama i osudama u 2015. Posjećeno na mrežnoj stranici: https://www. dzs.hr/ (01.02.2020.).

Državni zavod za statistiku, Godišnje statističko izvješće o punoljetnim počiniteljima kaznenih djela, prijavama, optužbama i osudama u 2016. Posjećeno na mrežnoj stranici: https://www. dzs.hr/ (01.02.2020.). 
Državni zavod za statistiku, Godišnje statističko izvješće o punoljetnim počiniteljima kaznenih djela, prijavama, optužbama i osudama u 2017. Posjećeno na mrežnoj stranici: https://www. dzs.hr/ (01.02.2020.).

Državni zavod za statistiku, Godišnje statističko izvješće o punoljetnim počiniteljima kaznenih djela, prijavama, optužbama i osudama u 2018. Posjećeno na mrežnoj stranici: https://www. dzs.hr/ (01.02.2020.).

ECPAT International (2018). Trends in online child sexual abuse material. Posjećeno na mrežnoj stranici: https://www.ecpat.org/wp-content/uploads/2018/07/ECPAT-International-Report-Trends-in-Online-Child-Sexual-Abuse-Material-2018.pdf (12.01.2020.).

EUROPOL (2019). Internet organised crime threat assessment (IOCTA). Posjećeno na mrežnoj stranici: https://www.europol.europa.eu/activities-services/main-reports/internet-organised-crime-threat-assessment-iocta-2019 (12.01.2020.).

European Statistics (Eurostat)(2018). Digital economy and society statistics - households and individual. Posjećeno na mrežnoj stranici: https://ec.europa.eu/eurostat/web/digital-economy-and-society/overview (12.01.2020.).

Europska komisija (2019). Study on Framework of best practices to tackle child sexual abuse online. Luxembourg: Publications Office of the European Union

Gillespie, A. (2010). Legal definitions of child pornography. Journal of Sexual Aggression, 16(1), 1931. doi: $10.1080 / 135526000903262097$

Greene, M. B. (2006). Bullying in schools: A plea for measureof human rights. Journal of Social Issues, 62(1), 63-79. doi: 10.1111/j.1540-4560.2006.00439.x

Greenfield, P., \& Yan, Z. (2006). Children, adolescents, and the Internet: A new field of inquiry in developmental psychology. Developmental psychology, 42(3),391. doi: 10.1037/00121649.42.3.391

Halonja, A. (2015). Anarhija u kiberprostoru. Hrvatskijezik: znanstveno-popularni časopis za kulturu hrvatskoga jezika, 2(1), 21-23.

Holden, M. K., \& Dyar, T. (2002). Virtual Environment Training - A New Tool for Neurorehabilitation? Neurology Report, 26(2), 62-71.

Holt, T. J. (2011). Crime online: Correlates, causes, and contexts. Durham, NC: Carolina Academic Press.

Hrabri telefon, Poliklinika za zaštitu djece grada Zagreba (2014). Istraživanje o iskustvima i ponašanju djece na internetu i društvenoj mreži Facebook. Posjećeno na mrežnoj stranici: https://www.poliklinika-djeca.hr/istrazivanja/istrazivanje-o-iskustvima-i-ponasanjima-djece-na-internetu-i-na-drustvenoj-mrezi-facebook-2/(05.12.2019.).

Hrkids.online (2017). Preliminarni rezultati nacionalnog istraživanja sigurnosti djece i mladih na internetu. Posjećeno na mrežnoj stranici: http://hrkids.online/ (12.01.2020.).

Interagency Working Group on Sexual Exploitation of Children (2016). Terminology guidelines for the protection of children from sexual exploitation and sexual abuse. ECPAT International \& ECPAT Luxembourg. http://luxembourgguidelines.org/(10.01.2020.).

Kazneni zakon. Narodne novine, 125/11, 144/12, 56/15, 61/15, 101/17, 118/18.

Konvencija o kibernetičkom kriminalu. Narodne novine, 9/02, 4/04.

Konvencija Vijeća Europe o zaštiti djece od seksualnog iskorištavanja i seksualnog nasilja. Narodne novine, MU 0/07. 
Menesini, E., \& Nocentini, A. (2009). Cyberbullying definition and measurement: Some critical considerations. Zeit schrift für Psychologie/Journal of Psychology, 217(4), 230-232. doi: 10.1027/0044-3409.217.4.230

Menesini, E., Nocentini, A., \& Calussi, P. (2011). The measurement of cyberbullying: Dimensional structure and relative item severity and discrimination. Cyberpsychology, behavior, and social networking, 14(5), 267-274. doi: 10.1089/cyber.2010.0002

Ministarstvo unutarnjih poslova (2017). Statistički pregled temeljnih sigurnosnih pokazatelja i rezultata rada u 2017. godini. Posjećeno na mrežnoj stranici: $h t t p s: / / m u p . g o v . h r / U s e r-$ Docs/mages/statistika/2018/Travanj/Statisticki\%20pregled\%202017.pdf (12.01.2020.).

Ministarstvo unutarnjih poslova (2018). Statistički pregled temeljnih sigurnosnih pokazatelja i rezultata rada u 2018. godini. Posjećeno na mrežnoj stranici: $h$ ttps://mup.gov.hr/UserDocs/mages/statistika/2019/Pregled\%20sigurnosnih\%20pokazatelja\%20u\%202018\%20 godini/Statisticki\%20pregled\%202018_web.pdf (12.01.2020.).

Ministarstvo unutarnjih poslova (2019). Pregled osnovnih sigurnosnih pokazatelja I.-XI. 2019. godine u Republici Hrvatskoj. Posjećeno na mrežnoj stranici: https://mup.gov.hr/UserDocs/mages/statistika/2019/Pregled\%20sigurnosnih\%20pokazatelja\%202019/Web_hrvatski_I-XI-2019.pdf (12.01.2020.).

Ministarstvo unutarnjih poslova. Posjećeno na mrežnoj stranici: https://policija.gov.hr/prevencija/ racunalna-sigurnost/seksualno-iskoristavanje-djece-putem-interneta-i-spolno-zlostavljanje/46 (12.01.2020.).

Mishna, F., Cook, C., Saini, M., Wu, M. J., \& MacFadden, R. (2009). Interventions for children, youth, and parents to prevent and reduce cyber abuse. Campbell Systematic Reviews, 5(1), i-54. doi: $10.4073 /$ csr.2009.2

Nacionalna strategija kibernetičke sigurnosti. Narodne novine, 108/2015.

Obradović, D. (2018). Kibernetika-što je to? In Common Foundations 2018-uniSTem: 6th Congressof Young Researchers in the Field of Civil Engineering and Related Sciences (pp. 158-163). Split: Fakultet građevinarstva, arhitekture i geodezije Sveučilišta u Splitu. doi: 10.31534/ CO/ZT.2018.22

OJJDP (2018). Commercial Sexual Exploitation of Children. Posjećeno na mrežnoj stranici: https:// ojjdp.ojp.gov/programs/commercial-sexual-exploitation-children (12.01.2020.).

Olweus, D. (2012). Cyberbullying: An overrated phenomenon? European Journal of Developmental Psychology, 9(5), 520-538. doi: 10.1080/17405629.2012.682358

Patchin, J. W., \& Hinduja, S. (2015). Measuring cyberbullying: Implications for research. Aggression and Violent Behavior, 23, 69-74. doi: 10.1016/j.avb.2015.05.013

Peterson, J., \& Densley, J. (2017). Cyberviolence: What do we know and where do we go from here? Aggression and violent behavior, 34, 193-200. doi: 10.1016/j.avb.2017.01.012

Polić, M. (2006). Uporaba umreženih računala u prevladavanju prostorno-vremenskih ograničenja u suvremenom obrazovanju. Metodički ogledi: časopis za filozofiju odgoja, 13(2), 77-94.

Pornography. Posjećeno na mrežnoj stranici: https://www.britannica.com/topic/pornography (20.01.2020.).

Rittossa, D. (2018). Kažnjavanje počinitelja najtežih seksualnih delikata na štetu djece u RH: zakonski okviri i postojeća sudska praksa. Hrvatski ljetopis za kaznene znanosti i praksu, 25 (2), 2018., 417-445. 
Schell, B. H., \& Martin, C. (2004). Contemporary world issues: Cybercrime. Santa Barbara, CA: $A B C-C L I O$.

Schell, B. H., Martin, M. V., Hung, P. C., \& Rueda, L. (2007). Cyber child pornography: A review paper of the social and legal issues and remedies-and a proposed technological solution. Aggression and Violent Behavior, 12(1), 45-63. doi: 10.1016/j.avb.2006.03.003

Schultze-Krumbholz, A., Göbel, K., Scheithauer, H., Brighi, A., Guarini, A., Tsorbatzoudis, H., ... \& Casas, J. A. (2015). A comparison of classification approaches for cyberbullying and traditional bullying using data from six European countries. Journal of School Violence, 14(1), 47-65. doi: 10.1080/15388220.2014.961067

Shariff, S., \& Gouin, R. (2006). Cyber-dilemmas: Gendered hierarchies, new technologies and cyber-safety in schools. Atlantis: Critical Studies in Gender, Culture \& Social Justice, 31(1), 27-37.

Statista (2019). Mobile internet traffic as percentage of total web trafficing August 2019, by region. Posjećeno na mrežnoj stranici: https://www.statista.com/statistics/306528/share-of-mobile-internet-traffic-in-global-regions/ (12.01.2020.)

Škrtić, D. (2013). Mamljenje djeteta za zadovoljenje spolnih potreba uporabom informacijsko-komunikacijske tehnologije. Zbornik Pravnog fakulteta Sveučilišta u Rijeci, 34(2), 1139-1170.

Tokunaga, R. S. (2010). Following you home from school: A critical review and synthesis of research on cyberbullying victimization. Computers in Human Behavior, 26(3), 277-287. doi: 10.1016/j.chb2009.11.014

Vandebosch, H., \& Van Cleemput, K. (2008). Defining cyberbullying: A qualitative research into the perceptions of youngsters. CyberPsychology \& Behavior, 11(4), 499-503. doi: 10.1089/ cpb.2007.0042

Vejmelka, L. (2012). Neke determinante vršnjačkog nasilja u adolescenciji. Ljetopis socijalnog rada, 19(2), 215-240.

Vejmelka, L. i Majdak, M. (2014). Specifičnosti nasilja kod djece smještene u domovima. Zbornik konferencije Nasilje na Internetu među i nad djecom i mladima. [The Specificities of Violence in Children Placed in Residential Care Institutions] Zagreb: Društvo za socijalnu podršku, 51-74.

Vejmelka, L., Brkić, G. i Radat, K. (2017). Dječja pornografija na internetu - Obilježja osuđenih počinitelja. Pravni vjesnik, 33(2), 77-100. doi: 10.25234/pv/4780

Vejmelka, L., Strabić, N. i Jazvo, M. (2017). Online aktivnosti i rizična ponašanja adolescenata u virtualnom okruženju. Društvena istraživanja: časopis za opća društvena pitanja, 26(1), 59-78. doi: 10.5559/di.26.1.04

Velki, T. i Vrdoljak, G. (2013). Uloga nekih vršnjačkih i školskih varijabli u predviđanju vršnjačkoga nasilnog ponašanja. Društvena istraživanja, 22(1), 101-120.

Veresha, R. (2018). Preventive measures against computer related crimes: Approaching an individual. Informatologia, 51(3-4), 189-199. doi: 10.32914/i.51.3-4.7

Vojković, G. i Štambuk-Sunjić, M. (2006). Konvencija o kibernetičkom kriminalu i Kazneni zakon Republike Hrvatske. Zbornik radova Pravnog fakulteta u Splitu, 43(1), 123-136.

Vuletić, S., Jeličić, A. i Karačić, S. (2014). Bioetičke konotacije interneta. Diacovensia: teološki prilo$z i, 22(4), 525-558$. 
Wall, D. S. (2004). Digital realism and the governance of spam as cybercrime. European Journal on Criminal Policy and Research, 10(4), 309-335.

Wall, D. S. (2015). The Internet as a conduit for criminal activity. In A. Pattavina (ed.) Information technology and the criminal justice system, pp. 77-98. Sage Publications, Inc. 
Lucija Vejmelka

University of Zagreb, Faculty of Law, Department of Social Work

Jakov Jurinić, Master of Social Work

\title{
TERMINOLOGY AND CONCEPTUALIZATION OF SEXUAL EXPLOITATION OF CHILDREN ON THE INTERNET
}

\begin{abstract}
Rarely do any types of crime provoke as much public condemnation as sexual abuse and exploitation of children, but the question arises as to how much they are recognized and taken seriously when they take place within virtual environment. Statistics serve as a good indicator in that respect since they show that the number of reports and convictions is not proportional to the number of sanctions imposed for the respective criminal offenses. Non-uniform terminology and different operational applications of the study of the phenomenon contribute to certain confusion within the public and professional discourse in the field of sexual abuse and exploitation of children on the Internet. For this reason, the authors of this paper seek to define in more detail the forms of abuse and exploitation of and among children on the Internet which allows for deeper understanding of this form of illegal activity.

Consequently, the purpose of this paper is to clarify key concepts and notions in the field of sexual exploitation of children and youth via the Internet and to provide an overview of scientific knowledge and national statistics in the field of sexual abuse and exploitation of children on the Internet that can benefit practitioners in their daily work, scientists planning research projects in this area and, last but not least, anyone involved in protecting children's well-being in the digital environment.
\end{abstract}

Key words: conceptualization of cyber abuse, sexual abuse and exploitation of children on the Internet, legislation, statistical indicators 